\title{
[3.2]Paracyclophane-10-enes and [3.2.3.2] Paracyclophane-10,27-dienes: A Convenient Synthesis by the McMurry Reaction and Dynamic Stereochemistry
}

\author{
Hans-Friedrich Grützmacher*, Ekkehard Neumann, Frank Ebmeyer ${ }^{*)}$, Karsten Albrecht, and Peter Schelenz
}

Fakultät für Chemie der Universität Bielefeld,

Postfach 8640, D-4800 Bielefeld

Received May 16, 1989

Key Words: Conformation analysis / McMurry reaction / [3.2]Paracyclophane-10-ene / Reductive coupling

The 1,3-bis(4-acylphenyl)propanes $2,3,9,12$, and 15 were subjected to a cyclization by reductive coupling with low-valent titanium (McMurry reaction). 2 and 3 are converted into the corresponding 10,11-dialkyl[3.2]paracyclophane-10-enes 4 and 5, respectively, under carefully controlled conditions in good yields. By the same method the dialdehydes 12 and 15 give rise to [3.2]paracyclophane-10-ene 13 and [3.2]metacyclophane-10-ene 16. However, the ditoluoyl derivative 9 gives rise only to the macrocyclic cyclophane 10 by dimerization. The corresponding macrocyclic cyclophanes 6 and 7 were also obtained from 2 and 3 , respectively. The conformational mobility of the cyclophanes 4,5 , and 13 was studied by variable-temperature ${ }^{1} \mathrm{H}-\mathrm{NMR}$, and $\Delta G^{*}=48-51 \mathrm{~kJ} / \mathrm{mol}$ was determined for the wobbling motion of the propano bridges.

The properties of the [3.2]cyclophanes have not been studied as extensively as those of the [2.2]cyclophanes, very likely because of the lack of a simple synthesis of the former. The asymmetrically bridged [3.2]cyclophanes cannot be prepared by the simple dimerization of a dihalide, and the usual synthetic routes are the desulfuration of a thia[3.3] cyclophane ${ }^{1)}$, a cyclization by the geminal dialkylation of diethyl malonate ${ }^{2)}$, a ring expansion of [2.2]cyclophanes ${ }^{3)}$, and an intramolecular Wurtz coupling of suitable precursors ${ }^{4}$. These preparations require many synthetic steps and the total yields are usually low. Hence, a convenient and efficient synthesis of [3.2]cyclophanes is of particular interest.

In the course of our studies of "twinned" cyclophanes" a synthesis producing [3.2] paracyclophane-10-enes in high yields was needed, and it appeared that the titanium-induced reductive coupling of appropriate diketones - the McMurry reaction ${ }^{6}$ - could be a suitable method. It is well known ${ }^{\text {") }}$ that the McMurry reaction is one of the best possibilities to synthesize sterically hindered alkenes. Furthermore, highly strained cyclic compounds were prepared by this method ${ }^{8)}$ also, but so far only the formation of additional bridges in cyclophanes ${ }^{9 \mathrm{a})}$ and the syntheses of macro-

\footnotetext{
*) New address: Institut für Organische Chemie, Universität Bonn, D-5300 Bonn.
}

\section{[3.2]Paracyclophan-10-ene und [3.23.2]Paracyclophan-10,27-diene: Eine einfache Synthese mit Hilfe der McMurray-Reaktion und dynamische Stereochemie}

Die 1,3-Bis(4-acylphenyl)propane 2, 3, 9, 12 und 15 wurden einer Cyclisierung durch reduktive Kupplung mit niedervalentem Titan (McMurry-Reaktion) unterworfen. 2 und 3 werden unter sorgfältig kontrollierten Bedingungen mit guten Ausbeuten in die 10,11Dialkyl[3.2]paracyclophan-10-ene 4 und 5 umgewandelt. Die beiden Dialdehyde 12 und 15 liefern nach der gleichen Methode ebenfalls [3.2] Paracyclophan-10-en 13 bzw. [3.2]Metacyclophan10-en 16. Das Ditoluoyl-Derivat 9 bildet dagegen durch eine Dimerisierung nur das makrocyclische Cyclophan 10. Die entsprechenden makrocyclischen Cyclophane 6 und 7 lassen sich auch aus 2 und 3 erhalten. Die konformative Beweglichkeit der Cyclophane 4, 5 und 13 wurde mit Hilfe von 'H-NMR bei verschiedenen Temperaturen untersucht und $\Delta \mathrm{G}^{*}=48-51 \mathrm{~kJ} / \mathrm{mol}$ für das Durchschwingen der Propano-Brŭcke bestimmt.

cyclic cyclophanes ${ }^{9 b)}$ were performed by the McMurry reaction. We now report the preparation of 10,11-dimethyl[3.2]paracyclophane-10-ene (4), 10,11-diethyl[3.2]paracyclophane-10-ene (5), [3.2]paracyclophane-10-ene (13), and [3.2]metacyclophane-10-ene (16) by the McMurry reaction with moderate to excellent yields. By varying slightly the reaction conditions the macrocyclic cyclophanes 10,11,27,28-tetramethyl[3.2.3.2]paracyclophane-10,27-diene (6), 10,11,27,28tetraethyl[3.2.3.2]paracyclophane-10,27-diene (7), and 10,11, 27,28-tetrakis(4-methylphenyl)[3.2.3.2]paracyclophane10,27-diene (10) are also obtained with an acceptable yield. Finally, the conformational mobility of the [3.2]paracyclophanes 4,5 , and 13 has been studied by variable-temperature ${ }^{1} \mathrm{H}-\mathrm{NMR}$.

\section{Synthesis}

In effect, the starting material for the synthesis of [3.2]paracyclophane-10-enes by the titanium-induced reductive coupling is the easily available 1,3-diphenylpropane ${ }^{10)}$ (1). The twofold and regioselective Friedel-Crafts acylation of 1 with acetyl chloride and propionyl chloride under optimized reaction conditions gave satisfactory yields of the corresponding 1,3-bis(4-acylphenyl)propane 2 and $3^{10)}$, respectively. The reversible acylation reaction strongly prefers a substitution at the para position of each of the phenyl groups, and no contamination with the sterically hindered 
ortho-substituted isomers is detected in the ${ }^{1} \mathrm{H}-\mathrm{NMR}$ spectra of $\mathbf{2}$ and $\mathbf{3}$. The diketones $\mathbf{2}$ and $\mathbf{3}$ are suitable substrates for a cyclization to [3.2]paracyclophanes by the McMurry reaction. Mass spectral studies of $1, \omega$-diphenylalkanes have indicated $^{11)}$ that 1 can adopt a conformation with a face-toface orientation of the two aromatic rings quite easily during its reactions. Assuming a similar conformational situation for the para-substituted derivatives $\mathbf{2}$ and $\mathbf{3}$ one would anticipate a facile cyclization to the [3.2]paracyclophanes 4 and 5. However, the yields were very low under the standard conditions of the McMurry reaction ${ }^{6}$ even when dilution techniques were used. Only if a very large molar excess $(>20: 1)$ of the titanium reagent was used and by slow addition (ca. $80 \mathrm{~h}$ ) of the diketone 2 and 3 to the Ti slurry, suspended in a large volume of THF or DME, the [3.2]paracyclophanes 4 and 5 respectively, were obtained in about $80 \%$ yield.
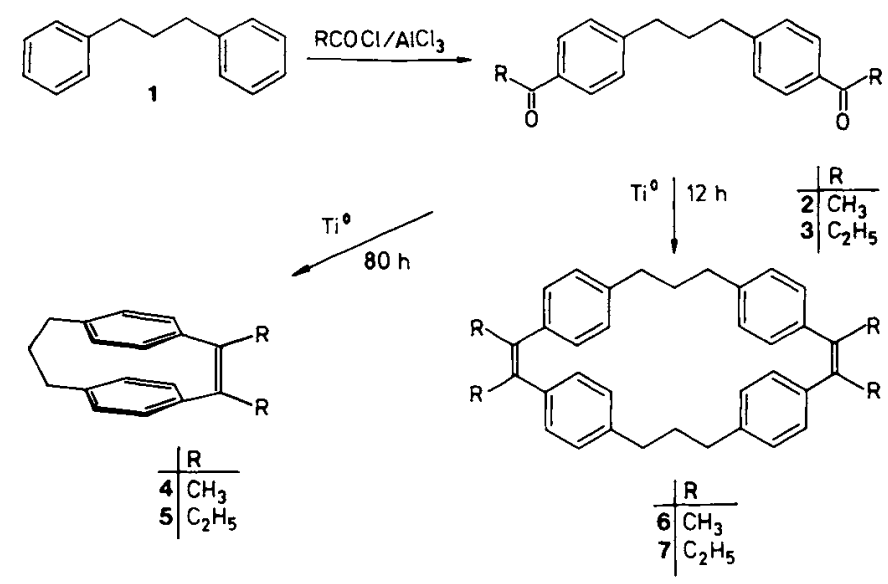

The macrocyclic [3.2.3.2] paracyclophane-10,27-dienes 6 and 7 were formed as byproducts $(<5 \%)$ under these reaction conditions and were separated from the corresponding monomeric coupling products 4 and 5 respectively, by flash chromatography. However, if the diketones $\mathbf{2}$ or $\mathbf{3}$ were added to the McMurry reagent within $12 \mathrm{~h}$ but with otherwise identical reaction conditions, the dimeric coupling products 6 or 7 were the main products.

The cyclization of 1,3-bis(4-aroylphenyl)propanes by the McMurry reaction should give rise to [3.2] paracyclophane10-enes substituted with aryl groups at the unsaturated bridge. A direct double aroylation of 9 by benzoyl chloride and $p$-toluoyl chloride was not successful. In contrast, 1,3bis(4-chloroformylphenyl)propane (8) obtained from 1 by the reaction with $\left(\mathrm{COCl}_{2} / \mathrm{AlCl}_{3}\right.$ and subsequent decarbonylation reacted smoothly with toluene to produce 1,3-bis(4methylbenzoyl)propane 9 under Friedel-Crafts conditions. However, the cyclization of 9 to the 10,11-bis(4-methylphenyl)[3.2]paracyclophane-10-ene failed even if extremely slow addition to the McMurry reagent and long reaction times were used. Instead, the dimeric coupling product, 10,11,27,28-tetrakis(4-methylphenyl)[3.2.3.2]paracyclophane-10,27-diene (10) was obtained with excellent yields. The formation of tetraarylethenes by the McMurry reaction is known ${ }^{5 a, 6)}$, but obviously in the present case the result is due to severe steric effects in the conformation necessary for the formation of the monomeric product and shows the limits of an intramolecular McMurry reaction for the synthesis of cyclophanes.
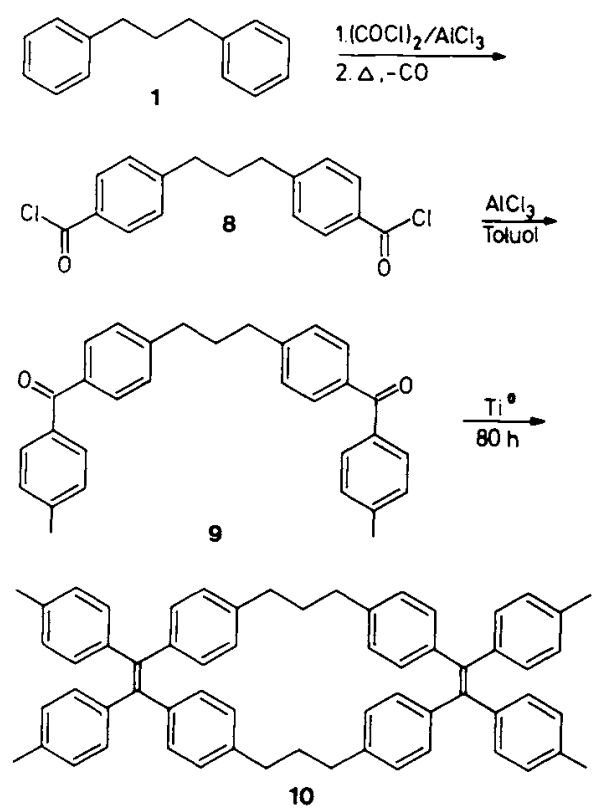

The [3.2]paracyclophane-10-ene 13 and the corresponding metacyclophane 16, both unsubstituted at the unsaturated bridge, should arise from the dialdehydes 1,3-bis(4formylphenyl)propane (12) and 1,3-bis(3-formylphenyl)propane (15), respectively, by the intramolecular McMurry reaction. A direct Rieche formylation of 1 in the meta positions of the aromatic rings to obtain $\mathbf{1 5}$ is not possible, and the corresponding reaction in the para positions to prepare 12 failed. Hence, both dialdehydes had to be prepared by rather elaborate synthetic routes ${ }^{5 c, 12)}$. The best results for 12 were obtained by PCC oxidation of the 1,3-bis(4-hydroxymethylphenyl)propane (11) $\left[\mathrm{LiAlH}_{4}\right.$ reduction of 1,3-bis(4ethoxycarbonylphenyl)propane via 8] and for 15 by formylation of the 1,3-bis(3-bromophenyl)propane (14) (via the
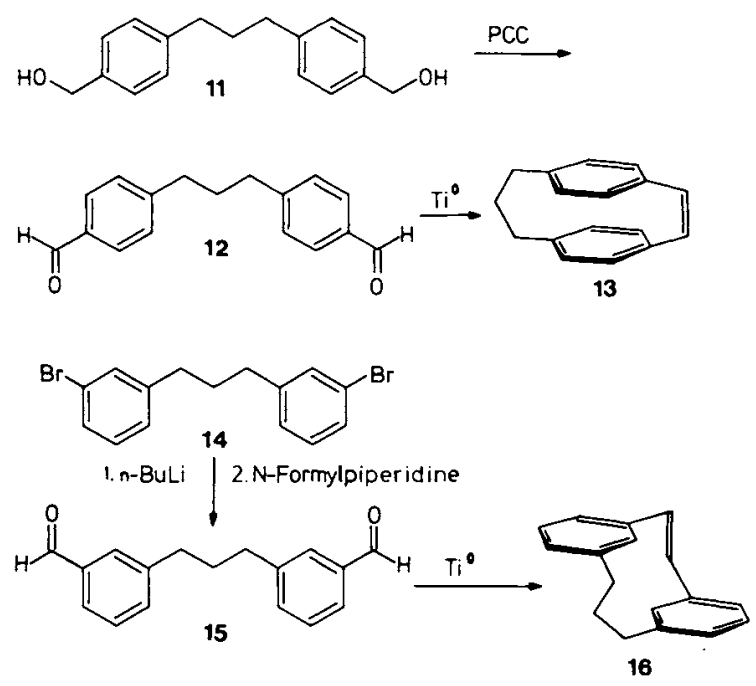
corresponding chalcone) with $N$-formylpiperidine/ $n \mathrm{BuLi}$. The intramolecular coupling of the para-dialdehyde 12 by the McMurry reaction using the same conditions as for $\mathbf{2}$ and 3 provided the [3.2] paracyclophane-10-ene 13, albeit in a rather poor yield of $8 \%$, together with the macrocyclic dimer $(11 \%)$. Better results were obtained for the corresponding cyclization of the meta-dialdehyde 15 which generated the [3.2] metacyclophane-10-ene 16 in $58 \%$ yield. In this case only a trace of the dimer was isolated.

The tetrasubstituted double bond in the bridge of 4 and 5 is resistant towards catalytic hydrogenation, while 13 and 16 can be converted quantitatively into the saturated [3.2]paracyclophane and [3.2]metacyclophane, respectively, by $\mathrm{Pd}(\mathrm{C}) / \mathrm{H}_{2}$. However, all cyclophanes $4,5,13$, and 16 react readily by the electrophilic addition of bromine.

\section{Dynamic Stereochemistry of the Paracyclophanes 4, 5, and 13}

The conformations and the conformational mobilities of the [3.2] paracyclophanes are of some interest in comparison to their next lower and higher homologues ${ }^{13)}$. The [2.2]paracyclophanes are rigid and strained molecules, while the unsubstituted [3.3]paracyclophane is a mobile molecule exhibiting a wobble motion of the bridges, and probably also a ring rotation ${ }^{14)}$. The conformational isomerism observed for [3.3]metacyclophanes is also attributed to a wobbling of the bridges of the syn conformer ${ }^{15)}$ giving rise to an interconversion between chair-chair, chair-boat, and boat-boat forms. This conformational interchange depends in some cases on the presence of heteroatoms in and substituents at the bridges ${ }^{14,16}$. A wobbling of the propano bridge can be expected also for the [3.2] paracyclophanes 4 , 5 , and 13 and may be effected by the substituents at the $C_{2}$ bridge. In order to analyze the dynamic processes, these cyclophanes were studied by variable-temperature ${ }^{1} \mathrm{H}-\mathrm{NMR}$ spectroscopy at $300 \mathrm{MHz}$ over the temperature range of 303 to $193 \mathrm{~K}$.

Above room temperature quite simple NMR spectra are obtained. The $300-\mathrm{MHz}{ }^{1} \mathrm{H}-\mathrm{NMR}$ spectrum of the $10,11-$ diethyl[3.2]paracyclophane-10-ene (5) is shown in Figure 1 as a typical example. The NMR spectra of the other [3.2]paracyclophanes differ qualitatively only by the signals due to the different substituents at the etheno bridge. The ${ }^{1} \mathrm{H}-\mathrm{NMR}$ spectrum $\left(\mathrm{CDCl}_{3}\right)$ of 5 exhibits at $302 \mathrm{~K}$ (Figure 1 a) the signals of an $\mathrm{AA}^{\prime} \mathrm{BB}^{\prime}$ spin system for the arene ring protons at $\delta=6.4-6.7$, showing a small upfield shift compared to the reference compound 1 as usual for cyclophanes with a face-to-face orientation of the aromatic groups ${ }^{14)}$. The protons at the trimethylene bridge give rise to a broad unstructured signal at $\delta=2.71$ for the two benzylic $\mathrm{CH}_{2}$ groups and to a not completely resolved quintuplet at $\delta=$ 2.10 for the central $\mathrm{CH}_{2}$. The remaining sharp signals at

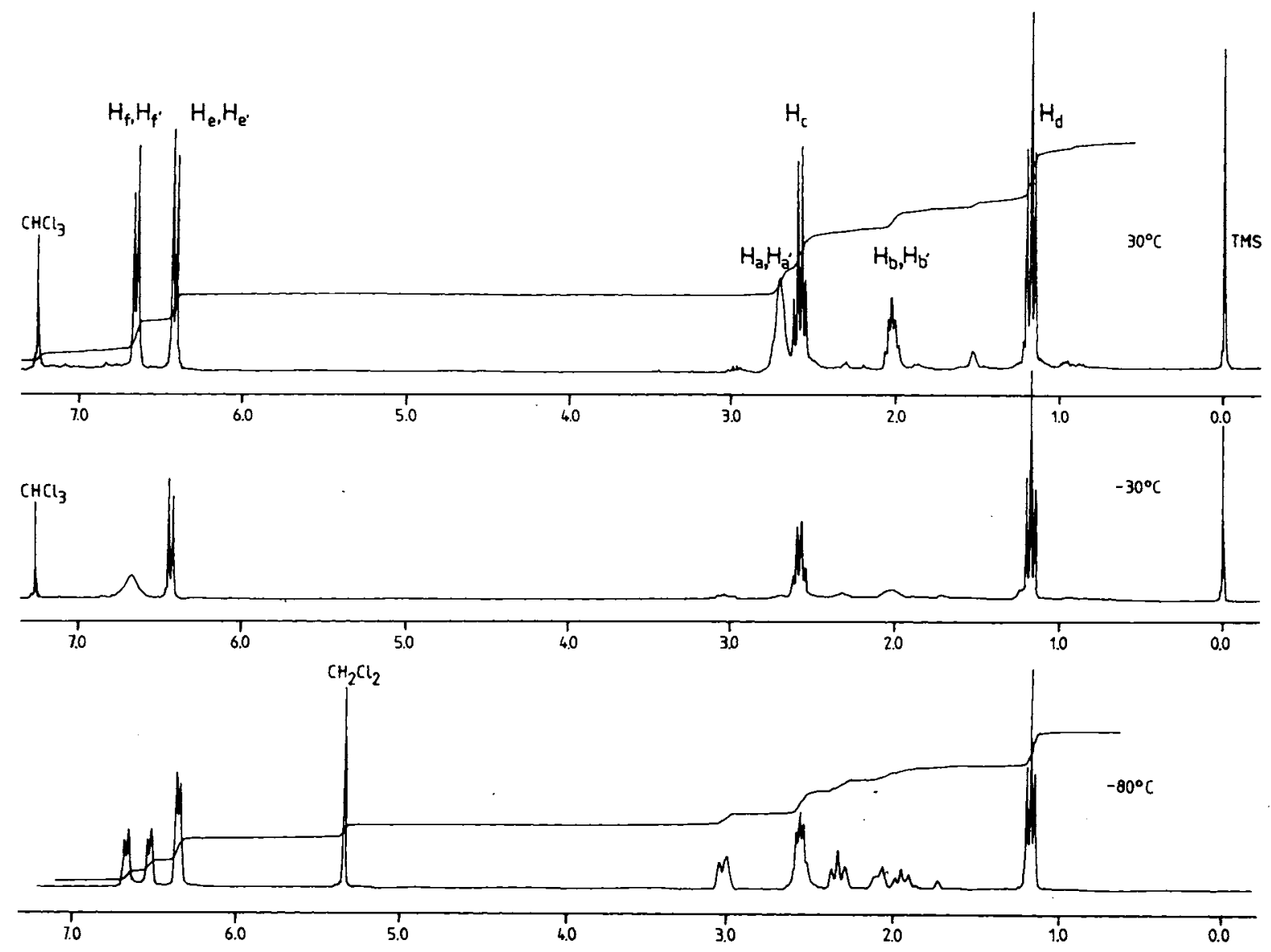

Figure 1. ${ }^{1} \mathrm{H}-\mathrm{NMR}$ spectrum of 10,11-diethyl[3.2]paracyclophane-10-ene at $302 \mathrm{~K}$ (a), $242 \mathrm{~K}$ (bi), $192 \mathrm{~K}$ (c) 
$\delta=2.60$ and 2.01 are due to the ethyl substituents at the etheno bridge.

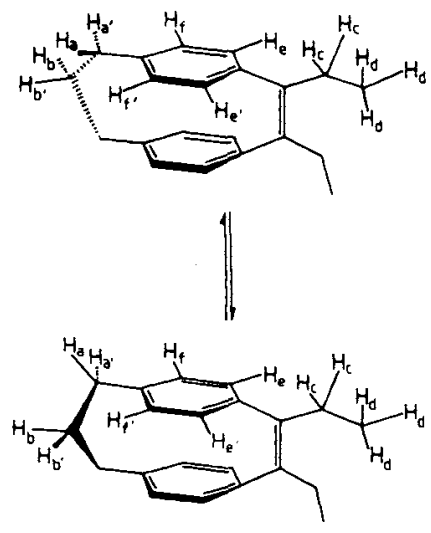

In particular the signals of the methylene protons at the propano bridge are broadened even at room temperature. On cooling the solution, a further broadening and eventually a coalescence is observed for these signals as well as for the low-field component of the aromatic $\mathrm{AA}^{\prime} \mathbf{B B}^{\prime}$ spin system (Figure $1 \mathrm{~b}$ ). At $192 \mathrm{~K}$ the spectrum shown in Figure $1 \mathrm{c}$ was observed. The $\mathrm{AA}^{\prime} \mathrm{BB}^{\prime}$ spin system of the protons at the aromatic rings has changed into an $\mathrm{ABCC}^{\prime}$ system with an unequal pair of protons $\left(\mathrm{H}_{\mathrm{f}}\right.$ and $\mathrm{H}_{\mathrm{f}}$, see formula in Figure 1) at the one ortho position giving rise to two doublets at $\delta=$ 6.54 and 6.69 , respectively, while the signal of the other pair of protons $\left(\mathrm{H}_{c}\right.$ and $\left.\mathrm{H}_{c}\right)$ remains unchanged. The protons $\mathrm{H}_{a}$ and $\mathrm{H}_{\mathrm{a}}$ at the benzylic positions of the propano bridge now appear as an AB spin system with a slightly diffuse doublet at $\delta=2.99\left({ }^{2} J_{\mathrm{aa}^{\prime}}=-14.8 \mathrm{~Hz}\right)$ and a triplet at $\delta=2.29$. This latter signal arises by a coincidence of the magnitude (ca. $14.5 \mathrm{~Hz}$ ) of the geminal coupling constant ${ }^{2} J_{\mathrm{aa}}$ and the vicinal coupling constant ${ }^{3} J_{\mathrm{ab}}$ of $\mathrm{H}_{\mathrm{a}}$ to $\mathrm{H}_{\mathrm{b}}$, at the central methylene group. This specifies a dihedral angle of almost $180^{\circ}$ between these two protons in a frozen propano bridge. Finally, $\mathrm{H}_{\mathrm{b}}$ and $\mathrm{H}_{\mathrm{b}}$ appear as a broad doublet at $\delta=2.03$ and a broad triplet at $\delta=1.90$, respectively. Not only the pattern for the signals of the propano bridge in the lowtemperature ${ }^{1} \mathrm{H}-\mathrm{NMR}$ spectrum but also the unusual splitting of the low-field signal of the ortho protons is in accord with a frozen trimethylene bridge, in which only the endooriented $\mathrm{H}_{\mathrm{b}}$, interferes with the neighboring proton of the aromatic ring. Additionally, the splitting of the ortho protons adjacent to the trimethylene bridge documents that the rings do not rotate at least at $192 \mathrm{~K}$, if at all. The conformations derived from the ${ }^{1} \mathrm{H}-\mathrm{NMR}$ spectra of 4,5 , and 13 agree very well with the conformations calculated by the MMPMI program ${ }^{17}$. The dihedral angle $\mathrm{H}_{\mathrm{x}^{\prime}}-\mathrm{C}(1)-\mathrm{C}(2)-$ $\mathrm{H}_{\mathrm{b}}$, within the propano bridge is calculated to be $179.7^{\circ}$ for all three cyclophanes. The distortion of the [3.2]paracyclophanes is seen from the endo and exo angles at the etheno bridges which are $116^{\circ}$ and $125^{\circ}$, respectively, deviating from the normal bond angle of $120^{\circ}$. Similarly the benzene rings are distorted into a boat form, and the bonds to the etheno bridge are bent additionally out of the plane of the rings in these calculated models.
Table 1. Coalescence temperature $\left(\mathrm{H}_{\mathrm{e}} / \mathrm{H}_{\mathrm{e}}\right)$ and $\Delta G^{\neq}$for the conformational motion of 4,5 , and $13\left(300-\mathrm{MHz}^{1} \mathrm{H} \mathrm{NMR}, \mathrm{CD}_{2} \mathrm{Cl}_{2}\right)$

\begin{tabular}{ccc} 
compound & $T_{\mathrm{c}}[\mathrm{K}]$ & $\Delta G^{*}[\mathrm{~kJ} / \mathrm{mol}]$ \\
\hline 13 & 248 & $50.7 \pm 1.0$ \\
4 & 243 & $48.7 \pm 1.0$ \\
5 & 243 & $49.5 \pm 1.0$ \\
\hline
\end{tabular}

$\Delta G^{*}$ of the wobble motion of the trimethylene bridge was determined by the coalescence temperature method for the cyclophanes 4,5 , and 13 , and the results are presented in Table 1. The values obtained vary slightly between 49 and $51 \mathrm{~kJ} / \mathrm{mol}$ but show no systematic effect of the substituents at the etheno bridge. Furthermore, $\Delta G^{*}$ for the wobble motion of the propano bridges of 4,5 , and 13 is not significantly different from the $\Delta G^{*}$ values of $48-49 \mathrm{~kJ} /$ mol observed for the same motion within [3.3]paracyclophane $^{(5)}$ and [3.3]metacyclophane ${ }^{16)}$. Obviously, the steric situation at the trimethylene bridges of the [3.2]cyclophanes and [3.3]cyclophanes is very similar in spite of the distortion of the former cyclophanes by the unsymmetrical bridges. This agrees with the assumption that the conformations of these cyclophanes and in particular the preference of the syn form of the [3.3]metacyclophanes is determined by the torsional strain (Pitzer strain) within the propano chains ${ }^{15}$.

The financial support by the Fonds der Chemischen Industrie is gratefully acknowledged. We thank Mr. E. Gärtner, Universität Bielefeld, for the measurements by high-resolution mass spectrometry and Mr. K.-P. Mester, Universität Bielefeld, for the measurements of the $300-\mathrm{MHz}$ NMR spectra. The skillful technical support by Mrs. A. Mülverstedt, Universität Bielefeld, is gratefully acknowledged.

\section{Experimental}

Melting points, uncorrected: Electrothermal melting point apparatus. - Infrared spectra: Perkin-Elmer Infrared Spectrophotometer 377 and 883, - UV spectra: Beckman Spectralphotometer UV 5240. - 'H-NMR spectra: Bruker AM 300 and Bruker WP 80; TMS as internal standard. - Mass spectra: Varian MAT $311 \mathrm{~A}$ direct insertion probe, $70 \mathrm{eV}$; high-resolution mass determinations with the same instrument at mass resolution $m / \Delta m=8000$. Thin layer chromatography: Merck silical gel DC $60 \mathrm{~F} 254$. Column chromatography: Merck silical gel 60 (70-230 mesh/ $0.063-0.2 \mathrm{~mm}$ ).

1.3-Bis(4-acetylphenyl)propane (2): $12.6 \mathrm{~g}(94.5 \mathrm{mmol})$ of anhydrous $\mathrm{AlCl}_{3}$ is suspended in $50 \mathrm{ml}$ of anhydrous 1,2-dichloroethane. $7.04 \mathrm{~g}(89.7 \mathrm{mmol})$ of acetyl chloride is added within $10 \mathrm{~min}$ to the stirred and cooled suspension followed by the addition of a solution of $5.50 \mathrm{~g}$ (28.1 mmol) of $1 \mathrm{in} 50 \mathrm{ml}$ of anhydrous 1,2-dichloroethane over a period of $50 \mathrm{~min}$. After stirring for $40 \mathrm{~h}$ at room temp. the reaction mixture is poured onto $500 \mathrm{~g}$ of ice. The aluminum hydroxide is dissolved by adding dropwise $2 \mathrm{~N} \mathrm{HCl}$. The organic layer is separated, and the aqueous residue is extracted twice with 100 $\mathrm{ml}$ of dichloromethane. The combined organic layers are dried with $\mathrm{Na}_{2} \mathrm{SO}_{4}$ and evaporated under reduced pressure. The residue is recrystallized from ethanol. - Yield $6.40 \mathrm{~g}(81 \%)$. - M.p. $84^{\circ} \mathrm{C}$ 
$\left(\right.$ ref. $\left.^{4)} 85-86.5^{\circ} \mathrm{C}\right)$. $-R_{\mathrm{f}}$ [petroleum ether/ethyl acetate $\left.(1: 1)\right]=$ 0.42. - IR $(\mathrm{KBr}): \tilde{v}=3030 \mathrm{~cm}^{-1}, 3000,2930,2910,2860(\mathrm{C}-\mathrm{H})$ $1675(\mathrm{C}=\mathrm{O}), 1600,1570\left(\mathrm{C}-\mathrm{C}_{\text {arom }}\right), 1440,1415,1360,850,835$, 815. - ${ }^{1} \mathrm{H} \mathrm{NMR}\left(\mathrm{CDCl}_{3}\right): \delta=2.03\left(\mathrm{~m}, 2 \mathrm{H}, \mathrm{CH}_{2} \mathrm{CH}_{2} \mathrm{CH}_{2}\right), 2.57$ (s, $\left.6 \mathrm{H}, \mathrm{CH}_{3}\right), 2.70\left(\mathrm{t},{ }^{3} \mathrm{~J}=6.8 \mathrm{~Hz}, 4 \mathrm{H}, \mathrm{CH}_{2} \mathrm{CH}_{2} \mathrm{CH}_{2}\right), 7.15-7.95$ (AA'BB', 8H, aromatic H). - MS $(70 \mathrm{eV}): m / z(\%)=280(46)$ $\left[\mathrm{M}^{+\cdot}\right], 265(100)\left[\mathrm{M}^{+\cdot}-\mathrm{CH}_{3}\right], 147(12), 134(23), 105(15), 43$ (66).

1.3-Bis (4-propionylphenyl) propane (3): $12.2 \mathrm{~g}(91.4 \mathrm{mmol})$ of anhydrous $\mathrm{AlCl}_{3}$ is suspended in $50 \mathrm{ml}$ of anhydrous 1,2-dichloroethane, and $7.45 \mathrm{~g}(80.5 \mathrm{mmol})$ of propionyl chloride is added within $10 \mathrm{~min}$ to the cooled mixture. Then, a solution of $5.00 \mathrm{~g}(25.5 \mathrm{mmol})$ of 1 in $50 \mathrm{ml}$ of 1,2-dichloroethane is added slowly within $45 \mathrm{~min}$. After stirring for $60 \mathrm{~h}$ at room temp. the reaction mixture is poured onto $500 \mathrm{~g}$ of ice. The workup occurs as with 2 , but recrystallization from methanol/ethanol/acetone $(1: 1: 1)$. - Yield $5.10 \mathrm{~g}(65 \%)$. M.p. $41^{\circ} \mathrm{C}$ (ref. ${ }^{4} 42.4-44^{\circ} \mathrm{C}$ ). $-R_{f}$ [petroleum ether/ethyl acetate $(1: 1]=0.55$. - IR (K Br): $\tilde{v}=2980 \mathrm{~cm}^{-1}, 2940,2860(\mathrm{C}-\mathrm{H})$, $1680(\mathrm{C}=\mathrm{O}), 1605\left(\mathrm{C}-\mathrm{C}_{\text {arom }}\right), 1450,1410,1375,1350,850,790$. ${ }^{1} \mathrm{H}$ NMR $\left(\mathrm{CDCl}_{3}\right): \delta=1.15\left(\mathrm{t},{ }^{3} \mathrm{~J}=7.1 \mathrm{~Hz}, 6 \mathrm{H}, \mathrm{CH}_{2} \mathrm{CH}_{3}\right), 1.99$ (m, $2 \mathrm{H}, \mathrm{CH}_{2} \mathrm{CH}_{2} \mathrm{CH}_{2}$ ), $2.67\left(\mathrm{t},{ }^{3} \mathrm{~J}=7.4 \mathrm{~Hz}, 4 \mathrm{H}, \mathrm{CH}_{2} \mathrm{CH}_{2} \mathrm{CH}_{2}\right), 2.91$ (q, $\left.{ }^{3} \mathrm{~J}=7.1 \mathrm{~Hz} .4 \mathrm{H}, \mathrm{CH}_{2} \mathrm{CH}_{3}\right), 7.12-7.95\left(\mathrm{AA}^{\prime} \mathrm{BB}^{\prime}, 8 \mathrm{H}\right.$, aromatic H). $-\mathrm{MS}(70 \mathrm{eV}): m / z(\%)=308(14)\left[\mathrm{M}^{+\cdot}\right], 279(100)\left[\mathrm{M}^{+\cdot}-\right.$ $\left.\mathrm{C}_{2} \mathrm{H}_{5}\right], 91$ (7), 57 (8).

10,11-Dialkyl/3.2/cyclophane-10-enes 4 and 5. - General Pro-

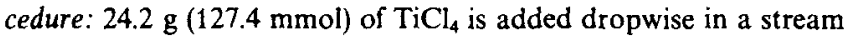
of nitrogen to $500 \mathrm{ml}$ of dry $\mathrm{THF}$ at $0^{\circ} \mathrm{C}$. After the addition of $23.9 \mathrm{~g}$ (365.0 mmol) of $\mathrm{Zn}$ dust and $1.00 \mathrm{~g}(12.60 \mathrm{mmol})$ of $\mathrm{dry}$ pyridine the mixture is stirred and refluxed for $2 \mathrm{~h}$. A solution of $2.00 \mathrm{mmol}$ of $2(3)$ in $100 \mathrm{ml}$ of dry THF is added dropwise within $80 \mathrm{~h}$ to this black reaction mixture using high-dilution techniques under continuous refluxing and stirring. The solution is refluxed for further $10 \mathrm{~h}(12 \mathrm{~h})$ and then cooled to room temp. Hydrolysis is achieved by addition of $250 \mathrm{ml}$ of a $10 \% \mathrm{~K}_{2} \mathrm{CO}_{3}$ solution. The insoluble residue is removed by filtration after the addition of 200 $\mathrm{ml}$ of dichloromethane and extracted twice with $100 \mathrm{ml}$ of dichloromethane. The combined organic layers are dried with $\mathrm{Na}_{2} \mathrm{SO}_{4}$ and evaporated under reduced pressure. The resulting residue is recrystallized from ethanol.

4: Yield $0.41 \mathrm{~g}(82 \%)$ - M.p. $147-149^{\circ} \mathrm{C}-R_{\mathrm{f}}\left(\mathrm{CH}_{2} \mathrm{Cl}_{2}\right)=$ 0.80. - IR (K Br): $\tilde{v}=3010 \mathrm{~cm}^{-1}, 2970,2840(\mathrm{C}-\mathrm{H}), 1605(\mathrm{C}=\mathrm{C}$, $\left.\mathrm{C}-\mathrm{C}_{\text {arom }}\right), 1440$. $-\mathrm{UV}\left(n\right.$-heptane): $\lambda_{\max }(\lg \varepsilon)=214 \mathrm{~nm}(4.138)$, 272 (2.952). - ' $\mathrm{H}$ NMR $\left(\mathrm{CDCl}_{3}\right): \delta=2.01\left(\mathrm{~m}, 2 \mathrm{H}, \mathrm{CH}_{2} \mathrm{CH}_{2} \mathrm{CH}_{2}\right)$, 2.19 (s, 6H, $\mathrm{CH}_{3}$ ), 2.70 (s, 4H, $\mathrm{CH}_{2} \mathrm{CH}_{2} \mathrm{CH}_{2}$ ), 6.40-6.70 ( $\mathrm{AA}^{\prime} \mathrm{BB}^{\prime}$, $8 \mathrm{H}$, aromatic $\mathrm{H})$. - MS $(70 \mathrm{eV}): m / z(\%)=248(100)\left[\mathrm{M}^{+\bullet}\right], 233$ (51) $\left[\mathrm{M}^{+\cdot}-\mathrm{CH}_{3}\right], 218$ (24), 203 (10), 141 (5), 129 (11), 91 (6).

$$
\begin{array}{ll}
\mathrm{C}_{19} \mathrm{H}_{20}(248.4) & \text { Calcd. C } 91.88 \text { H } 8.12 \\
& \text { Found C } 90.93 \text { H } 8.03
\end{array}
$$

Calcd. 248.1565 Found 248.1564 (MS)

5: Yield $0.33 \mathrm{~g}(60 \%)$. - M.p. $190^{\circ} \mathrm{C} .-R_{f}\left(\mathrm{CH}_{2} \mathrm{Cl}_{2}\right)=0.81$. IR $(\mathrm{KBr}): \tilde{v}=3020 \mathrm{~cm}^{-1}, 2960,2870,2850(\mathrm{C}-\mathrm{H}), 1595(\mathrm{C}=\mathrm{C})$, 1460. - UV ( $n$-heptane): $\lambda_{\max }(\lg \varepsilon)=215 \mathrm{~nm}$ (4.217), 274 (3.053). - 'H NMR $\left(\mathrm{CDCl}_{3}\right): \delta=1.18\left(\mathrm{t},{ }^{3} J=7.4 \mathrm{~Hz}, 6 \mathrm{H}\right.$, $\left.\mathrm{CH}_{2} \mathrm{CH}_{3}\right), 2.10\left(\mathrm{~m}, 2 \mathrm{H}, \mathrm{CH}_{2} \mathrm{CH}_{2} \mathrm{CH}_{2}\right), 2.60(\mathrm{q}, J=7.4 \mathrm{~Hz}, 4 \mathrm{H}$, $\left.\mathrm{CH}_{2} \mathrm{CH}_{3}\right), 2.71\left(\mathrm{~s}, 4 \mathrm{H}, \mathrm{CH}_{2} \mathrm{CH}_{2} \mathrm{CH}_{2}\right), 6.39-6.70\left(\mathrm{AA}^{\prime} \mathrm{BB}^{\prime}, 8 \mathrm{H}\right.$, aromatic $\mathrm{H}) .-\mathrm{MS}(70 \mathrm{eV}): m / z(\%)=276(100)\left[\mathrm{M}^{+\cdot}\right], 247(39)$ $\left[\mathrm{M}^{+\cdot}-\mathrm{C}_{2} \mathrm{H}_{5}\right], 218(24), 203(10), 141$ (5), $129(11), 91$ (6).

$$
\begin{array}{ll}
\mathrm{C}_{21} \mathrm{H}_{24}(276.4) & \text { Calcd. C } 91.25 \text { H } 8.75 \\
& \text { Found C } 90.33 \text { H } 8.77
\end{array}
$$

Calcd. 276.1878 Found 276.1876 (MS)

10,11,27,28-Tetraalkyl/3.2.3.27paracyclophane-10,27-dienes 6 and 7. - General Procedure: $30.0 \mathrm{ml}(270 \mathrm{mmol})$ of $\mathrm{TiCl}_{4}$ is added dropwise at $0^{\circ} \mathrm{C}$ to 1.51 of absolute THF under nitrogen. After the addition of $22.0 \mathrm{~g}$ (340 mmol) of $\mathrm{Zn}$ dust and $1.00 \mathrm{~g}$ (12.6 mmol) of dry pyridine the mixture is refluxed for $2 \mathrm{~h}$, and a solution of $14.0 \mathrm{mmol}$ of $2(3)$ in $50 \mathrm{ml}$ of absolute THF is added dropwise to this black reaction mixture within $12 \mathrm{~h}(10 \mathrm{~h})$ using high-dilution techniques under continuous stirring and refluxing. Then, the reaction mixture is cooled and hydrolyzed with $300 \mathrm{ml}$ of a $10 \%$ $\mathrm{K}_{2} \mathrm{CO}_{3}$ solution. After filtration the organic layer can be separated by addition of diethyl ether, and the insoluble residue is extracted twice with diethyl ether. The organic layers are washed with water, dried with $\mathrm{Na}_{2} \mathrm{SO}_{4}$, and evaporated under reduced pressure. The colourless residue is recrystallized from toluene.

6: Yield $1.12 \mathrm{~g}(32 \%)$. - M.p. $192^{\circ} \mathrm{C}$. $-R_{\mathrm{f}}$ [petroleum ether ethyl acetate $(1: 1)]=0.79 .-I R(K B r): \tilde{v}=3019 \mathrm{~cm}^{-1}, 2993$, $2924,2850(\mathrm{C}-\mathrm{H}), 1608,1506\left(\mathrm{C}=\mathrm{C}, \mathrm{C}-\mathrm{C}_{\text {arom }}\right), 1435,1019,844$, $828,812,726$. - UV (n-heptane): $\lambda_{\max }(\lg \varepsilon)=278 \mathrm{~nm}(4.853)$. ${ }^{1} \mathrm{H} \mathrm{NMR}\left(\mathrm{CDCl}_{3}\right): \delta=1.68$ (quint, ${ }^{3} \mathrm{~J}=7.3 \mathrm{~Hz}, 4 \mathrm{H}, \mathrm{CH}_{2} \mathrm{CH}_{2} \mathrm{CH}_{2}$ ), $2.16\left(\mathrm{~s}, 12 \mathrm{H}, \mathrm{CH}_{3}\right), 2.35\left(\mathrm{t},{ }^{3} \mathrm{~J}=7.3 \mathrm{~Hz}, 8 \mathrm{H}, \mathrm{CH}_{2} \mathrm{CH}_{2} \mathrm{CH}_{2}\right), 6.80(\mathrm{~s}$, $16 \mathrm{H}$, aromatic $\mathrm{H})$. - MS $(70 \mathrm{eV}): m / z(\%)=496(100)\left[\mathrm{M}^{+\cdot}\right]$, 219 (23), 205 (21), 129 (22), 117 (18), 91 (28).

$$
\begin{aligned}
& \mathrm{C}_{38} \mathrm{H}_{40} \text { (496.7) Calcd. C } 91.88 \text { H } 8.12 \\
& \text { Found C } 91.80 \text { H } 8.56
\end{aligned}
$$

\section{Calcd. 496.3130 Found 496.3130 (MS)}

7: Yield $2.24 \mathrm{~g}(58 \%)$ - M.p. $209^{\circ} \mathrm{C}$. $-R_{\mathrm{f}}$ [petroleum ether/ ethyl acetate $(1: 1)]=0.81 .-$ IR $(\mathrm{KBr}): \tilde{v}=3017 \mathrm{~cm}^{-1}, 2969$, 2939, $2861(\mathrm{C}-\mathrm{H}), 1508\left(\mathrm{C}-\mathrm{C}_{\text {arom }}\right), 1454,1321,1122,1022,838$, 818, 790. - UV (n-heptane): $\lambda_{\max }(\lg \varepsilon)=272 \mathrm{~nm}(4.762) .-{ }^{1} \mathrm{H}$ NMR $\left(\mathrm{CDCl}_{3}\right): \delta=0.98\left(\mathrm{t}^{3} \mathrm{~J}=7.4 \mathrm{~Hz}, 12 \mathrm{H}, \mathrm{CH}_{2} \mathrm{CH}_{3}\right), 1.64$ (quint, ${ }^{3} \mathrm{~J}=6.9 \mathrm{~Hz}, \mathrm{CH}_{2} \mathrm{CH}_{2} \mathrm{CH}_{2}$ ), $2.31\left(\mathrm{t},{ }^{3} \mathrm{~J}=6.9 \mathrm{~Hz}, 8 \mathrm{H}\right.$, $\left.\mathrm{CH}_{2} \mathrm{CH}_{2} \mathrm{CH}_{2}\right), 2.55\left(\mathrm{q},{ }^{3} \mathrm{~J}=7.4 \mathrm{~Hz}, 8 \mathrm{H}, \mathrm{CH}_{2} \mathrm{CH}_{3}\right), 6.77(\mathrm{~s}, 16 \mathrm{H}$, aromatic $\mathrm{H}) .-\mathrm{MS}(70 \mathrm{eV}): m / z(\%)=552(100)\left[\mathrm{M}^{+\bullet}\right)$, all signals of fragment ions $>14 \%$

$$
\begin{array}{ll}
\mathrm{C}_{42} \mathrm{H}_{48} \text { (552.8) } & \text { Calcd. C } 91.25 \text { H } 8.75 \\
& \text { Found C } 91.30 \text { H } 8.78
\end{array}
$$

Calcd. 552.3756 Found 552.3756 (MS)

1,3-Bis (4-chloroformylphenyl) propane (8): A solution of $9.50 \mathrm{~g}$ (75.0 mmol) of oxalyl chloride in $25 \mathrm{ml}$ of dry dichloromethane is added dropwise to a stirred suspension of $10.0 \mathrm{~g}(75.0 \mathrm{mmol})$ of anhydrous $\mathrm{AlCl}_{3}$ in $100 \mathrm{ml}$ of dry dichloromethane at $-15^{\circ} \mathrm{C}$. The reaction mixture is stirred for further $30 \mathrm{~min}$ at this temp., and a solution of $4.00 \mathrm{~g}(20.4 \mathrm{mmol})$ of 1 in $50 \mathrm{ml}$ of dry dichloromethane is added at $-15^{\circ} \mathrm{C}$ within $30 \mathrm{~min}$. The reaction mixture is stirred for $5 \mathrm{~h}$ at $-15^{\circ} \mathrm{C}$ and then poured onto $500 \mathrm{~g}$ of ice. The organic phase is separated, and the aqueous phase is extracted with three portions of $100 \mathrm{ml}$ of diethyl ether/dichloromethane $(1 ; 1)$. The combined organic phases are dried with $\mathrm{Na}_{2} \mathrm{SO}_{4}$. After evaporation of the solvent the yellow product is suspended in $100 \mathrm{ml}$ of anhydrous chlorobenzene and refluxed for $5 \mathrm{~h}$. The solvent is evaporated under reduced pressure, and the yellow crude material is used without further purification. - Yield $5.24 \mathrm{~g}(80 \%)$.

1,3-Bis/4-(4-methylbenzoyl)phenyl/propane (9): $4.00 \mathrm{~g}(12.50$ mmol) 8 is suspended in $100 \mathrm{ml}$ of anhydrous toluene. At $0^{\circ} \mathrm{C} \mathrm{a}$ suspension of $6.50 \mathrm{~g}$ (48.74 mmol) of anhydrous $\mathrm{AlCl}_{3}$ in $100 \mathrm{ml}$ of dry toluene is added cautiously. The reaction mixture is stirred for $1 \mathrm{~h}$ at $0^{\circ} \mathrm{C}$ and $18 \mathrm{~h}$ at room temp. The mixture is poured onto $400 \mathrm{~g}$ of ice, the organic phase is separated, and the aqueous layer is extracted twice with $100 \mathrm{ml}$ of dichloromethane. The combined organic phases are dried with $\mathrm{Na}_{2} \mathrm{SO}_{4}$ and purified by filtration through a $2.5-\mathrm{cm}$ layer of silica gel. The silica gel layer is extracted with petroleum ether/ethylacetate (1:1). The combined organic phases are evaporated, and the slighly pink residue is recrystallized 
from ethyl acetate. - Yield $2.25 \mathrm{~g}(42 \%)$ - M.p. $143-144^{\circ} \mathrm{C}$. $R_{f}$ [petroleum ether/ethyl acetate $\left.(1: 1)\right]=0.56 .-$ IR $(\mathrm{KBr}): \tilde{\mathrm{v}}=$ $3050 \mathrm{~cm}^{-1}, 2940,2880(\mathrm{C}-\mathrm{H}), 1675(\mathrm{C}=\mathrm{O}), 1605,1570\left(\mathrm{C}-\mathrm{C}_{\text {arom }}\right)$, $1415,1360,815,800$. - 'H NMR $\left(\mathrm{CDCl}_{3}\right): \delta=1.99(\mathrm{~m}, 2 \mathrm{H}$, $\left.\mathrm{CH}_{2} \mathrm{CH}_{2} \mathrm{CH}_{2}\right), 2.38\left(\mathrm{~s}, 6 \mathrm{H}, \mathrm{CH}_{3}\right), 2.70\left(\mathrm{t},{ }^{3} \mathrm{~J}=7.2 \mathrm{~Hz}, 4 \mathrm{H}\right.$, $\left.\mathrm{CH}_{2} \mathrm{CH}_{2} \mathrm{CH}_{2}\right), 7.10-7.85\left(2 \mathrm{AA}^{\prime} \mathrm{BB}^{\prime}, 16 \mathrm{H}\right.$, aromatic $\left.\mathrm{H}\right) . \mathrm{MS}(70$ $\mathrm{eV}): m / z(\%)=432(70)\left[\mathrm{M}^{+}\right], 341(16), 223(12), 210(22), 119$ (100), 91 (29).

10,11,27,28-Tetrakis (4-methylphenyl) [3.2.3.2/paracyclophane-

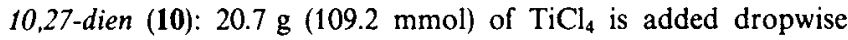
under nitrogen within $30 \mathrm{~min}$ at $0^{\circ} \mathrm{C}$ to $400 \mathrm{ml}$ of anhydrous dioxane. After the addition $14.0 \mathrm{~g}(214.0 \mathrm{mmol})$ of $\mathrm{Zn}$ dust is added, and the mixture is refluxed for $2 \mathrm{~h}$. A solution of $0.65 \mathrm{~g}(1.500 \mathrm{mmol})$ of 9 in $100 \mathrm{ml}$ of anhydrous dioxane is added dropwise to the black reaction mixture over $80 \mathrm{~h}$ using high-dilution techniques continuing the refluxing and stirring. After the addition the mixture is further refluxed for $10 \mathrm{~h}$ to complete the reaction and then cooled and hydrolized with $300 \mathrm{ml}$ of $10 \%$ aqueous solution of $\mathrm{K}_{2} \mathrm{CO}_{3}$. $200 \mathrm{ml}$ of dichloromethane is added, the unsoluble residue filtered off and extracted twice with $100 \mathrm{ml}$ of dichloromethane. The combined organic layers are dried with $\mathrm{Na}_{2} \mathrm{SO}_{4}$ and evaporated under reduced pressure. The residue is purified by column chromatography on silica gel using dichloromethane as eluent. - Yield $0.09 \mathrm{~g}$ $(6.6 \%)$. M.p. $355^{\circ} \mathrm{C}$. $-R_{\mathrm{f}}\left(\mathrm{CH}_{2} \mathrm{Cl}_{2}\right)=0.81$. $-\mathrm{IR}(\mathrm{KBr}): \tilde{\mathrm{v}}=$ $3080 \mathrm{~cm}^{-1}, 3050,3020,2990,2930,2860(\mathrm{C}-\mathrm{H}), 1610,1510,1440$, $1410\left(\mathrm{C}=\mathrm{C}, \mathrm{C}-\mathrm{C}_{\text {arom }}\right), 840,820,810$ - UV (n-heptane): $\lambda_{\max }$ $(\lg \varepsilon)=212 \mathrm{~nm}$ (4.453), 248 (4.302), 290 (3.952), 320 (4.034). $-{ }^{1} \mathrm{H}$ NMR $\left(\mathrm{CDCl}_{3}\right): \delta=1.73\left(\mathrm{~m}, 4 \mathrm{H}, \mathrm{CH}_{2} \mathrm{CH}_{2} \mathrm{CH}_{2}\right), 2.28\left(\mathrm{~s}, 12 \mathrm{H}, \mathrm{CH}_{3}\right)$, $2.41\left(\mathrm{t}, 8 \mathrm{H}, \mathrm{CH}_{2} \mathrm{CH}_{2} \mathrm{CH}_{2}\right), 6.85\left(\mathrm{AA}^{\prime} \mathrm{BB}^{\prime}, 16 \mathrm{H}\right.$, aromatic $\mathrm{H}$, endocyclic), 6.93 ( $\mathrm{AA}^{\prime} \mathrm{BB}^{\prime}, 16 \mathrm{H}$, aromatic $\mathrm{H}$, exocyclic). - MS (70 eV): $m / z(\%)=800(100)\left[\mathrm{M}^{+\cdot}\right], 400(21), 105(8)$.

\section{$\mathrm{C}_{62} \mathrm{H}_{56}$ Calcd. 800.4382 Found 800.4384 (MS)}

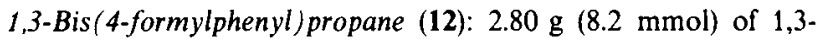
bis(4-ethoxycarbonylphenyl)propane in $100 \mathrm{ml}$ of dry THF is added slowly to a suspension of $3.00 \mathrm{~g}(78 \mathrm{mmol})$ of $\mathrm{LiAlH}_{4}$ in $100 \mathrm{ml}$ of dry THF and eventually refluxed for ca. $12 \mathrm{~h}$. The reaction mixture is hydrolyzed and acidified with dilute $\mathrm{HCl}$ and thoroughly extracted with dichloromethane. The organic extracts are dried with $\mathrm{Na}_{2} \mathrm{SO}_{4}$, and the crude 1,3-bis (4-hydroxymethylphenyl) propane (11) $1.80 \mathrm{~g}, 86 \%)$ is used without further purification.

$1.80 \mathrm{~g}(7.0 \mathrm{mmol})$ of 11 is redissolved in $50 \mathrm{ml}$ of dichloromethane and treated with $43.4 \mathrm{~g}$ of $\mathrm{PCC} / \mathrm{Al}_{2} \mathrm{O}_{3}(1 \mathrm{~g} \cong 1 \mathrm{mmol}$ of $\mathrm{PCC})$ for $2 \mathrm{~h}$ at room temp. The reaction mixture is filtered, and the residue is rinsed with dichloromethane. The combined organic filtrates are evaporated under reduced pressure. The crude product $12(1.30 \mathrm{~g})$ is purified by column chromatography using ethyl acetate as the eluent. - Yield $1.30 \mathrm{~g}(71 \%)$. - M.p. $252^{\circ} \mathrm{C}$. $-R_{f}$ (ethyl acetate) $=0.68 .-\operatorname{IR}(\mathrm{KBr}): \tilde{v}=3031 \mathrm{~cm}^{-1}, 2940,2858(\mathrm{C}-\mathrm{H}), 1697$ $(\mathrm{C}=\mathrm{O}), 1605,1576\left(\mathrm{C}-\mathrm{C}_{\mathrm{arom}}\right) \cdot-{ }^{1} \mathrm{H} \mathrm{NMR}\left(\mathrm{CD}_{3} \mathrm{Cl}\right): \delta=2.10(\mathrm{~m}$, $2 \mathrm{H}, \mathrm{CH}_{2} \mathrm{CH}_{2} \mathrm{CH}_{2}$ ), 2.75 (t, 4 H, $\mathrm{CH}_{2} \mathrm{CH}_{2} \mathrm{CH}_{2}$ ), 7.26-7.87 (AA'BB', $8 \mathrm{H}$, aromatic $\mathrm{H}), 9,99(\mathrm{~s}, 2 \mathrm{H}, \mathrm{HCO})$. $-\mathrm{MS}(70 \mathrm{eV}): m / z(\%)=$ $252(14)\left[\mathrm{M}^{+\cdot}\right], 133(23), 120(19), 105(44), 103$ (19), 92 (73), 91 (100), 79 (12), 77 (43).

[3.2]Paracyclophane-10-ene (13): $19.0 \mathrm{~g} \mathrm{(100} \mathrm{mmol)} \mathrm{of} \mathrm{TiCl}_{4}$ is slowly added in a stream of nitrogen to $1000 \mathrm{ml}$ of absolute dimethoxyethane at $-20^{\circ} \mathrm{C}$ using an apparatus for high dilution. After stirring for additional $30 \mathrm{~min}, 13.3 \mathrm{~g}(200 \mathrm{mmol})$ of $\mathrm{Zn}(\mathrm{Cu})$ and $1.4 \mathrm{ml}$ of pyridine are added, and the black-greenish mixture is refluxed for $2 \mathrm{~h}$. Then, $1.20 \mathrm{~g}(4.70 \mathrm{mmol})$ of 12 in $100 \mathrm{ml}$ of absolute dimethoxyethane is added continuously within $60 \mathrm{~h}$ followed by refluxing of the mixture for further $12 \mathrm{~h}$. After cooling to room temp. the mixture is hydrolyzed carefully by the addition of
$300 \mathrm{ml}$ of a $10 \% \mathrm{~K}_{2} \mathrm{CO}_{3}$ solution and stirring for $4 \mathrm{~h}$. The residue formed is filtered off, and the residue and the filtrate are extracted with diethyl ether. The combined organic solutions are dried with $\mathrm{Na}_{2} \mathrm{SO}_{4}$, concentrated under reduced pressure, and filtered through a layer of silica gel. After evaporation the crude material $(300 \mathrm{mg}$ ) is purified by column chromatography using $\mathrm{CCl}_{4}$ as eluent. Yield $0.14 \mathrm{~g}(14 \%)$. $-R_{\mathrm{f}}\left(\mathrm{CCl}_{4}\right)=0.68$. - A sample is further purified by HPLC (Milton Roy, Model III; column RP 18, 10 ; eluent $\left.\mathrm{CH}_{3} \mathrm{OH}\right)$. - IR (KBr): $\tilde{v}=3018 \mathrm{~cm}^{-1}, 2932,2848(\mathrm{C}-\mathrm{H})$, 1597, $1511\left(\mathrm{C}=\mathrm{C}, \mathrm{C}-\mathrm{C}_{\mathrm{arom}}\right), 1437,1400,1109,963,888,803,779$, 708. - ${ }^{1} \mathrm{H} \mathrm{NMR}\left(\mathrm{CDCl}_{3}\right): \delta=2.03$ (quint, $2 \mathrm{H}, \mathrm{CH}_{2} \mathrm{CH}_{2} \mathrm{CH}_{2}$ ), 2.71 (m, not resolved, $4 \mathrm{H}, \mathrm{CH}_{2} \mathrm{CH}_{2} \mathrm{CH}_{2}$ ), 6.43-6.68 (AA' $\mathrm{BB}^{\prime}, 8 \mathrm{H}$, aromatic $\mathrm{H}), 7.21(\mathrm{~s}, 2 \mathrm{H}, \mathrm{CH}=\mathrm{CH})$ - $\mathrm{MS}(70 \mathrm{eV}): m / z(\%)=220$ (100) $\left[\mathrm{M}^{+\cdot}\right], 219(17), 205(20), 191$ (17), $189(16), 178(14), 165$ (16), $115(29), 91$ (9), 89 (13).

\section{$\mathrm{C}_{17} \mathrm{H}_{16}$ Calcd. 220.1252 Found 220.1252 (MS)}

During the column chromatography $0.11 \mathrm{~g}(8.1 \%)$ of the macrocyclic dimer has been isolated from the fractions after the elution of 13 . However, the dimer is contaminated with about $10 \%$ of an impurity of higher molecular weight, which could not be separated by chromatography. - MS $(70 \mathrm{eV}): m / z(\%)=440(100)\left[\mathrm{M}^{+\cdot}\right]$, $220.5(2.5)\left[{ }^{13} \mathrm{M}^{2+}\right], 220(13)\left[\mathrm{M}^{2+}\right], 219(18), 207(15), 206(10), 193$ (12), 191 (11), 178 (6), 165 (4), 129 (7), 117 (12), 105 (8), 91 (16).

\section{$\mathrm{C}_{34} \mathrm{H}_{32}$ Calcd. 440.2503 Found 440.2504 (MS)}

1,3-Bis (3-formylphenyl) propane (15): $56.0 \mathrm{ml}(89.0 \mathrm{mmol})$ of $n$ BuLi is added slowly to a solution of $10.0 \mathrm{~g}(28.2 \mathrm{mmol})$ of $14 \mathrm{in}$ $200 \mathrm{ml}$ of absolute diethyl ether at $0-5^{\circ} \mathrm{C}$ in a stream of nitrogen. The mixture is stirred at $0^{\circ} \mathrm{C}$ for $4 \mathrm{~h}$ yielding an intensively red solution. After cooling to $-5^{\circ} \mathrm{C} 12.4 \mathrm{ml}(112 \mathrm{~mol})$ of $N$-formylpiperidine is added within $90 \mathrm{~min}$; during this time the colour of the suspension changes from red to pale yellow. Stirring is continued over night at room temperature. The reaction mixture is acidified with dilute $\mathrm{HCl}$ and extracted with several portions of dichloromethane. The combined organic phases are washed successively with $10 \% \mathrm{NaHCO}_{3}$ solution and $\mathrm{H}_{2} \mathrm{O}$ and evaporated under reduced pressure. The residue is redissolved in diethyl ether and again extracted three times with $\mathrm{H}_{2} \mathrm{O}$, dried with $\mathrm{Na}_{2} \mathrm{SO}_{4}$, and then evaporated. The crude product is purified by column chromatography using dichloromethane as eluent giving a colourless oil. - Yield $3.40 \mathrm{~g}(49 \%) .-R_{\mathrm{f}}\left(\mathrm{CH}_{2} \mathrm{Cl}_{2}\right)=0.32$. - IR $(\mathrm{KBr}): \tilde{v}=3030 \mathrm{~cm}^{-1}$, 2932, $2664(\mathrm{C}-\mathrm{H}), 1693(\mathrm{C}=\mathrm{O}), 1606,1588\left(\mathrm{C}-\mathrm{C}_{\mathrm{arom}}\right) .-{ }^{1} \mathrm{H}$ NMR $\left(\mathrm{CDCl}_{3}\right): \delta=2.10\left(\mathrm{q}, 2 \mathrm{H}, \mathrm{CH}_{2} \mathrm{CH}_{2} \mathrm{CH}_{2}\right), 2.78(\mathrm{t}, 4 \mathrm{H}$, $\left.\mathrm{CH}_{2} \mathrm{CH}_{2} \mathrm{CH}_{2}\right), 7.25-7.75(\mathrm{~m}, 8 \mathrm{H}$, aromatic $\mathrm{H}), 9.90(\mathrm{~s}, 2 \mathrm{H}$, $\mathrm{HCO})$. - MS $(70 \mathrm{eV}): m / z(\%)=252(94)\left[\mathrm{M}^{+\cdot}\right], 133(60), 120$ (49), 119 (62), 105 (66), 103 (20), 92 (100), 91 (91), 79 (23), 77 (28).

[3.2 JMetacyclophane-10-ene (16): $11.6 \mathrm{ml}(100 \mathrm{mmol})$ of $\mathrm{TiCl}_{4}$ is added dropwise in a stream of nitrogen to $300 \mathrm{ml}$ of absolute dimethoxyethane at $-70^{\circ} \mathrm{C}$, followed by the slow addition of $13.3 \mathrm{~g}$ $(200 \mathrm{mmol})$ of $\mathrm{Zn}(\mathrm{Cu})$ and $1.4 \mathrm{ml}$ of pyridine. The mixture is refluxed for $1 \mathrm{~h}$. Then, $0.50 \mathrm{~g}(1.98 \mathrm{mmol})$ of $15 \mathrm{in} 100 \mathrm{ml}$ of absolute dimethoxymethane is added to the black-greenish slurry using highdilution techniques within $60 \mathrm{~h}$ under continuous refluxing and stirring. The reaction is completed by further refluxing for $12 \mathrm{~h}$. The workup followed the procedure given for 13 and the crude material $(0.45 \mathrm{~g})$ was purified twice by column chromatography using petroleum ether/ethyl acetate $(9: 1)$ and $n$-heptane as the eluents giving a colourless oil. - Yield $0.25 \mathrm{~g}(58 \%)$. $-R_{\mathrm{f}}$ [petroleum ether/ethyl acetate $(9: 1)]=0.46 .-I R(\mathrm{KBr}): \tilde{v}=3050 \mathrm{~cm}^{-1}$, $3008,2913,2855(\mathrm{C}-\mathrm{H}), 1600,1576\left(\mathrm{C}=\mathrm{C}, \mathrm{C}-\mathrm{C}_{\text {arom }}\right), 1475,1450$, $1430,955,820,752,718 .-{ }^{1} \mathrm{H}$ NMR $\left(\mathrm{CCl}_{4}\right): \delta=1.92(\mathrm{q}, 2 \mathrm{H}$, $\left.\mathrm{CH}_{2} \mathrm{CH}_{2} \mathrm{CH}_{2}\right), 2.43\left(\mathrm{t}, 4 \mathrm{H}, \mathrm{CH}_{2} \mathrm{CH}_{2} \mathrm{CH}_{2}\right), 6.05$ (s, $2 \mathrm{H}$, aromatic $\mathrm{H}_{\mathrm{i}}$, 
anti conformation), $6.65(\mathrm{~s}, 2 \mathrm{H}, \mathrm{CH}=\mathrm{CH}), 6.8-7.3(\mathrm{~m}, 6 \mathrm{H}$, aromatic H). - MS $(70 \mathrm{eV}): m / z(\%)=220(100)\left[\mathrm{M}^{+\cdot}\right], 219(32)$, 218 (13), 205 (45), 203 (32), 192 (54), 191 (91), 190 (20), 178 (29), 165 (12). $\mathrm{C}_{17} \mathrm{H}_{16}$ Calcd. 220.1252 Found 220.1252 (MS)

From a later fraction during the column chromatography $10 \mathrm{mg}$ $(2.3 \%)$ of the macrocyclic dimer have been obtained. - MS (70 $\mathrm{eV}): m / z(\%)=440(100)\left[\mathrm{M}^{+} \cdot\right], 220.5(2.3)\left[{ }^{13} \mathrm{M}^{2+}\right], 220(15)$ $\left[\mathrm{M}^{2+}\right], 208$ (14), 205 (19), 203 (12), 193 (19), 191 (18), 179 (13), 178 (19), 165 (10), 129 (16), 117 (17), 105 (17), 91 (24).

$$
\mathrm{C}_{34} \mathrm{H}_{32} \text { Calcd. } 440.2303 \text { Found } 440.23 \text { (MS) }
$$

\section{CAS Registry Numbers}

1: 1081-75-0 / 2: 6337-58-2 / 3: 20176-53-8 / 4: 121732-50-1/ 5: 121732-54-5 / 6: 121733-06-0 / 7: 121733-07-1 / 8: 101443-92-9/9 121733-08-2 / 10: 121733-09-3 / 11: 121733-11-7/ 12: 118852-20-3 / 13: 49576-90-1 / 13 (dimer): 121733-12-8 / 14: 121733-14-0/15: 121733-13-9 / 16: 121733-15-1 / 16 (dimer): 121733-16-2 / ClCO$\mathrm{CH}_{2} \mathrm{CH}_{3}: 79-03-8 /(\mathrm{COCl})_{2}: 79-37-8$ / toluene: 108-88-3/1,3-bis(4-ethoxycarbonylphenyl)propane: 121733-10-6

\footnotetext{
1) S. E. Potter, H. Steinberg, J. Chem. Soc., Chem. Commun. 1973, 520

2) R. W. Griffin, Jr., R. A. Coburn, Tetrahedron Lett. 1964, 2571.

${ }^{3)}$ D. J. Cram, R. C. Helgeson, J. Am. Chem. Soc. 88 (1966) 3516.

4) D. J. Cram, H. Steinberg, J. Am. Chem. Soc. 73 (1951) 5691.
}

5) Sa) H.-E. Grützmacher, W. Husemann, Tetrahedron Lett. 26 (1985) 2431. - ${ }^{5 b)}$ E. Neumann, H.-F. Grützmacher, to be published. - ${ }^{c)}$ E. Neumann, Dissertation, Universität Bielefeld, 1989.

6) 6a) J. E. McMurry, M. P. Flemming, J. Am. Chem. Soc. 96 (1974) 4708. - ${ }^{6 b)}$ J. E. McMurry, K. L. Kees, J. Org. Chem. 42 (1977) 2655. - ${ }^{6 c)}$ D. Lenoir, Synthesis 1977, 553.

7) J. E. McMurry, M. P. Flemming, K. L. Kees, L. R. Krepski, $J$. Org. Chem. 43 (1978) 3255.

${ }^{8)}$ For a typical example see J. E. McMurry, G. J. Haley, J. R. Matz, J. C. Clardy, G. V. Duyne, J. Am. Chem. Soc. 106 (1984) 5018.

9) 9a) H. Hopf, C. Mlynek, J. Org. Chem., submitted for publication. - ${ }^{96}$ D. Tanner, O. Wennerström, Acta Chem. Scand., Ser. B. 37 (1983) 693 .

10) H. A. Weidlich, M. Meyer-Delius, Chem. Ber. 74 (1941) 1195.

11) D. Kuck, H.-F. Grützmacher, Z. Naturforsch., Teil B, 34 (1979) 1750.

12) F. Ebmeyer, Diplomarbeit, Universität Bielefeld, 1986.

${ }^{13)}$ For a review see R. H. Mitchell in Cyclophanes (P. M. Keehn, S. M. Rosenfeld, Eds.) vol. 1, p. 239, Academic Press, New York 1983.

14) R. Benn, N. E. Blank, M. W. Haenel, J. Klein, A. R. Koray, K. Weidenhammer, L. M. Ziegler, Angew. Chem. 92 (1980) 45; Angew. Chem. Int. Ed. Engl. 19 (1980) 44.

15) M. F. Semmelhack, J. J. Harrison, D. C. Young, A. Guitierrez, S. Rafii, J. Clardy, J. Am. Chem. Soc. 107 (1985) 7508.

16) Y. Fukazawa, Y. Takeda, S. Usui, M. Kodama, J. Am. Chem. Soc. 110 (1982) 7842.

17) 17a) J. J. Gajewski, K. E. Gilbert, MMPMI, QCPE, Indiana, 1986. - ${ }^{176)}$ R. M. Jarret, M. Saunders, STRPI, Yale Rapid Interactive Structure Input Program, Yale University 1983, modified for MMPMI by J. J. Gajewski, K. E. Gilbert, Indiana, 1986.

[151/89] 